\title{
A placebo-controlled blind trial of cyclosporin-A in prevention of corneal graft rejection in rabbits
}

\author{
T. A. G. BELL', D. L. EASTY'. AND K. G. MCCULLAGH \\ From the 'Bristol Eve Hospital and ${ }^{2}$ Searle Research and Development
}

SUMMARY Cyclosporin-A (CyA) administered to rabbits intramuscularly in a dose of $25 \mathrm{mg} / \mathrm{kg} / \mathrm{day}$ for 14 days following interlamellar corneal grafting had a significant effect in preventing rejection of the corneal graft $(p<0 \cdot 05)$, and the benefit was maintained. Rejection was attended by an initial mild inflammatory reaction and followed by a protracted intense response involving a variety of cell types, with subsequent loss of epithelium, endothelium and keratocytes, and the development of areas of stromal necrosis. CyA suppressed this rejection response.

Cyclosporin A, a cyclic polypeptide produced by a variety of fungi, has been shown to have a marked immunosuppressive action when given for short periods at the time of sensitisation in a variety of immunological experiments in rats and mice.' It appears that the drug impairs the early stage of antigenic sensitisation of immunocompetent lymphoid cells. ${ }^{12}$ The drug has been shown to prolong survival of organ transplants in animals ${ }^{34}$ and man. ${ }^{5}$ The purpose of the present study was to determine by a placebo-controlled blind trial the effect of $\mathrm{CvA}$ in preventing corneal graft rejection in rabbits and to describe the rejection process following interlamellar corneal grafting and simultaneous skin grafting.

\section{Materials and Methods}

INTERLAMELLAR GRAFTING

Outbred New Zealand White rabbits (3-4 kg) were used. The technique used was based on that described by Basu and Ormsby. ${ }^{6}$ A $5 \mathrm{~mm}$ penetrating donor button was placed in a half-depth pouch in the recipient cornea. This was fashioned by cutting a partial-depth corneal incision close to the superior limbus and dissecting downwards with a lamellar dissector. Stitches were not used.

\section{SKIN GRAFTING}

A $5 \mathrm{~cm}$ square piece of shaved abdominal skin was removed from the donor rabbit, cut into 4 squares, and each inserted into small pockets fashioned under

Correspondence to Mr D. L. Eastv. Bristol Eve Hospital, Lower Maudlin Street. Bristol BS1 2LX. the skin of the abdomen of the recipient rabbit. This was performed at the time of corneal grafting in order to ensure maximal rejection of the corneal graft. ${ }^{6}$ Plastic spray was applied to the skin incisions and penicillin 100000 units administered intramuscularly for 4 davs.

TREATMENT

A heat sterilised preparation of CyA in olive oil (50 $\mathrm{mg} / \mathrm{ml}$ ) was prepared in $2 \mathrm{ml}$ glass vials. Sterilised olive oil was prepared in the same way as a placebo. The preparations were coded and paired, and they were administered by intramuscular injection to 13 pairs of rabbits such that one of each pair received CyA $25 \mathrm{mg} / \mathrm{kg} /$ day and the other placebo.

\section{Results}

Slit-lamp examination was performed throughout the 14 davs following grafting and comparisons of the observations made at 7 days and at 14 days. Thereafter 2 pairs were maintained without treatment for a further 8 weeks. Histological examination of corneal tissue was performed at 2 weeks and at 10 weeks.

In both groups during the first 7 days blood vessels grew into the region of the incision, and inflammatory cells were apparent in the recipient stroma. The vessels were more apparent in untreated rabbits. At 7 days 2 of the untreated rabbits had developed marked vascularisation and oedema of the recipient stroma (Table 1). Small opacities between the donor button and recipient cornea were present in both groups.

At 14 days (Table 1) 9 untreated rabbits showed marked rejection with opacification and vascularisa- 


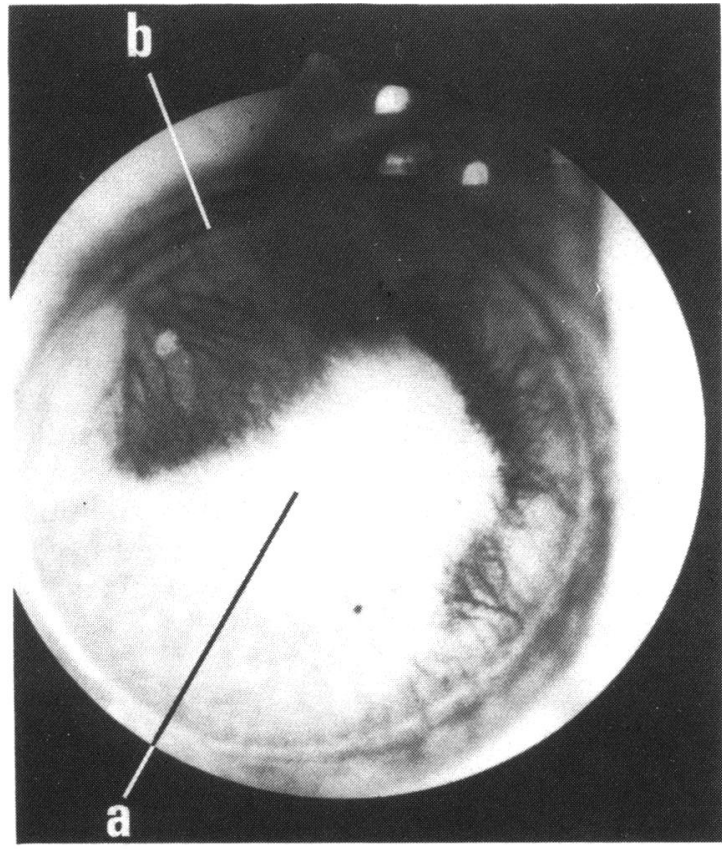

$1 \mathrm{a}$

Fig. 1 Rabbit cornea. (a) Untreated rabbit at 25 davs showing intense vascularisation and oedema extending into central donor button (a). Incision (b). (b) CyA treated rabbit at 25 davs showing clear recipient cornea and donor button. Interspace opacities outline the margin of donor tissue (a). (c) CyA treated rabbit at 10 weeks. The donor button has become incorporated and remains clear (a).

tion of the proximal recipient stroma. Eleven treated animals showed no clinical evidence of rejection, and the corneae were completely free of vessels and opacification.

At 4 weeks the rejection process in the untreated rabbits was maximal (Fig. 1a), while at 6 weeks resolution was noted with reduction in oedema. vascularisation, and the appearance of macrophages infiltrating the recipient stroma and graft button. Treated rabbits (Fig. 1 b) remained free of inflammation: at 6 weeks macrophages were again noted.

At 10 weeks (Fig. 1c) in untreated rabbits the

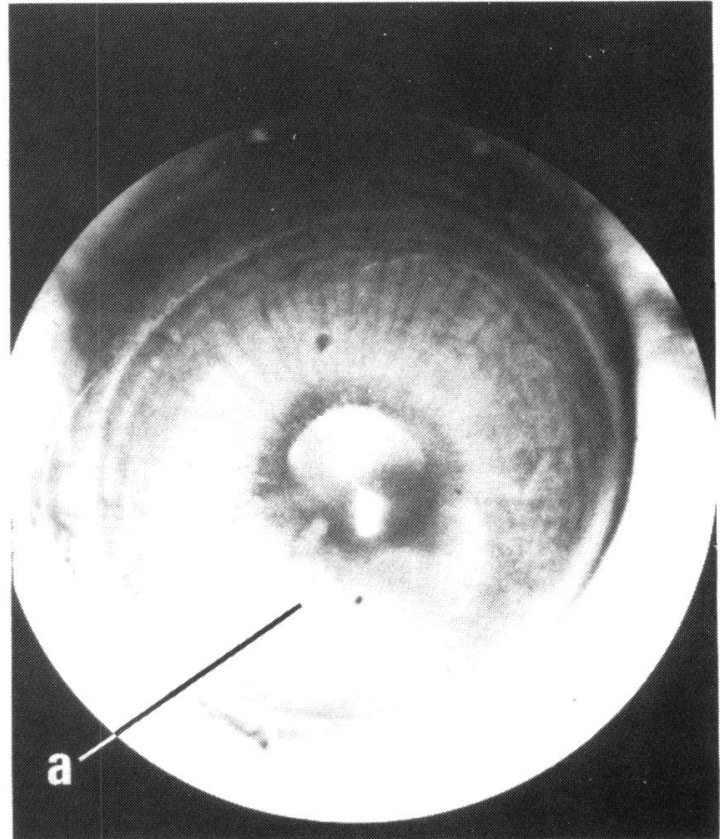

$1 \mathrm{~b}$

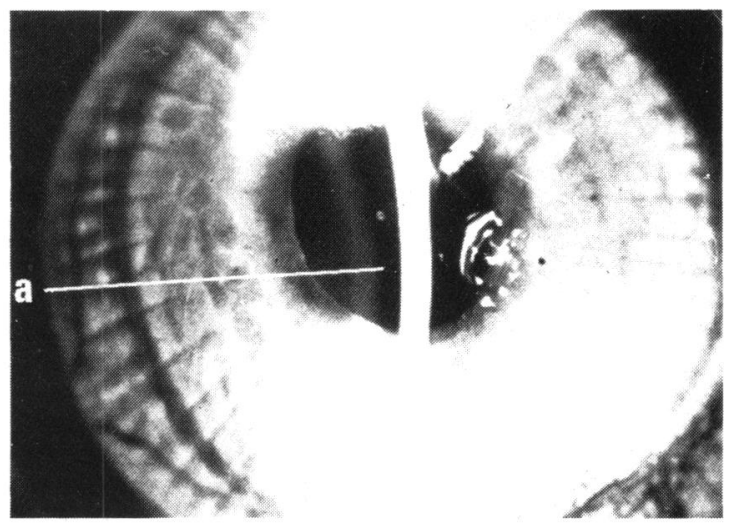

1c

proximal recipient stroma was no longer oedematous but was diffusely opaque. Within the deep stroma of the graft button opacities were noted. At the same stage in treated rabbits the graft edges were indistinct following incorporation of the graft into the recipient tissue. Fig. 2 shows the sequence of events in (a) untreated and (b) treated rabbits.

Opacification and vascularisation of the recipient stroma, opacification of the graft button, and limbal injection were regarded as potential criteria of graft rejection and were graded according to severity in treated and untreated animals. Stromal opacification 

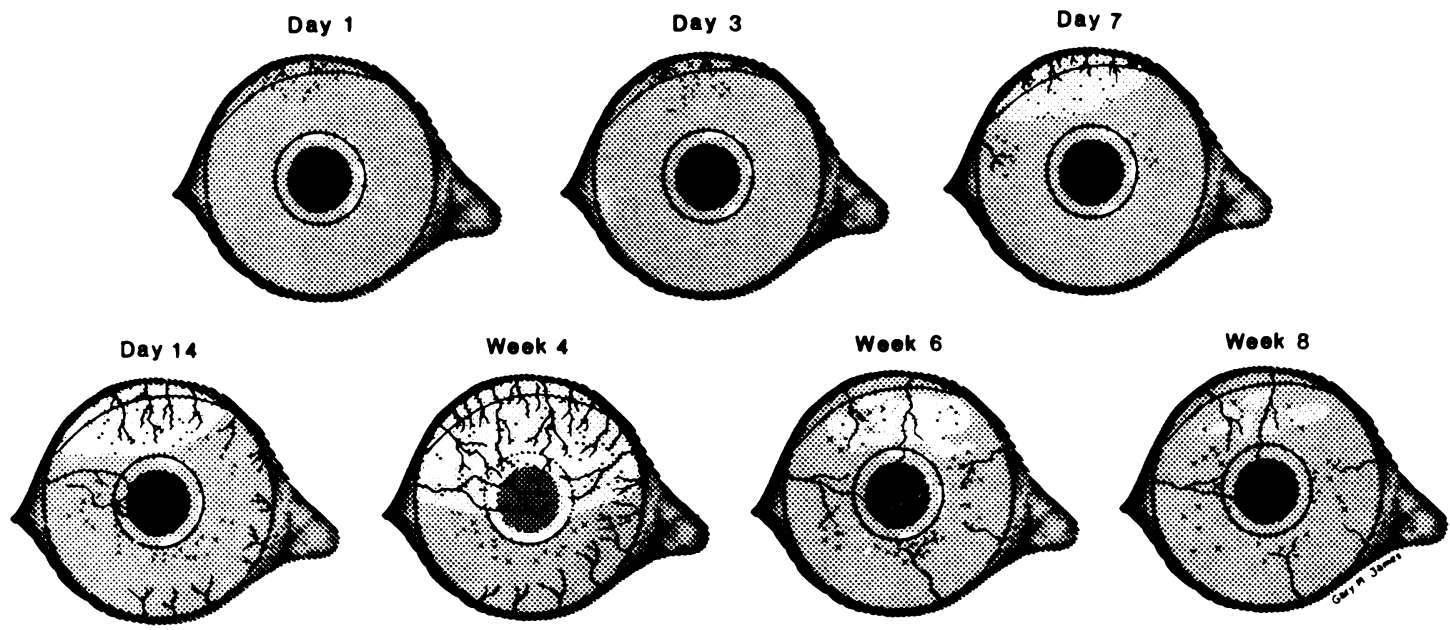

2 a
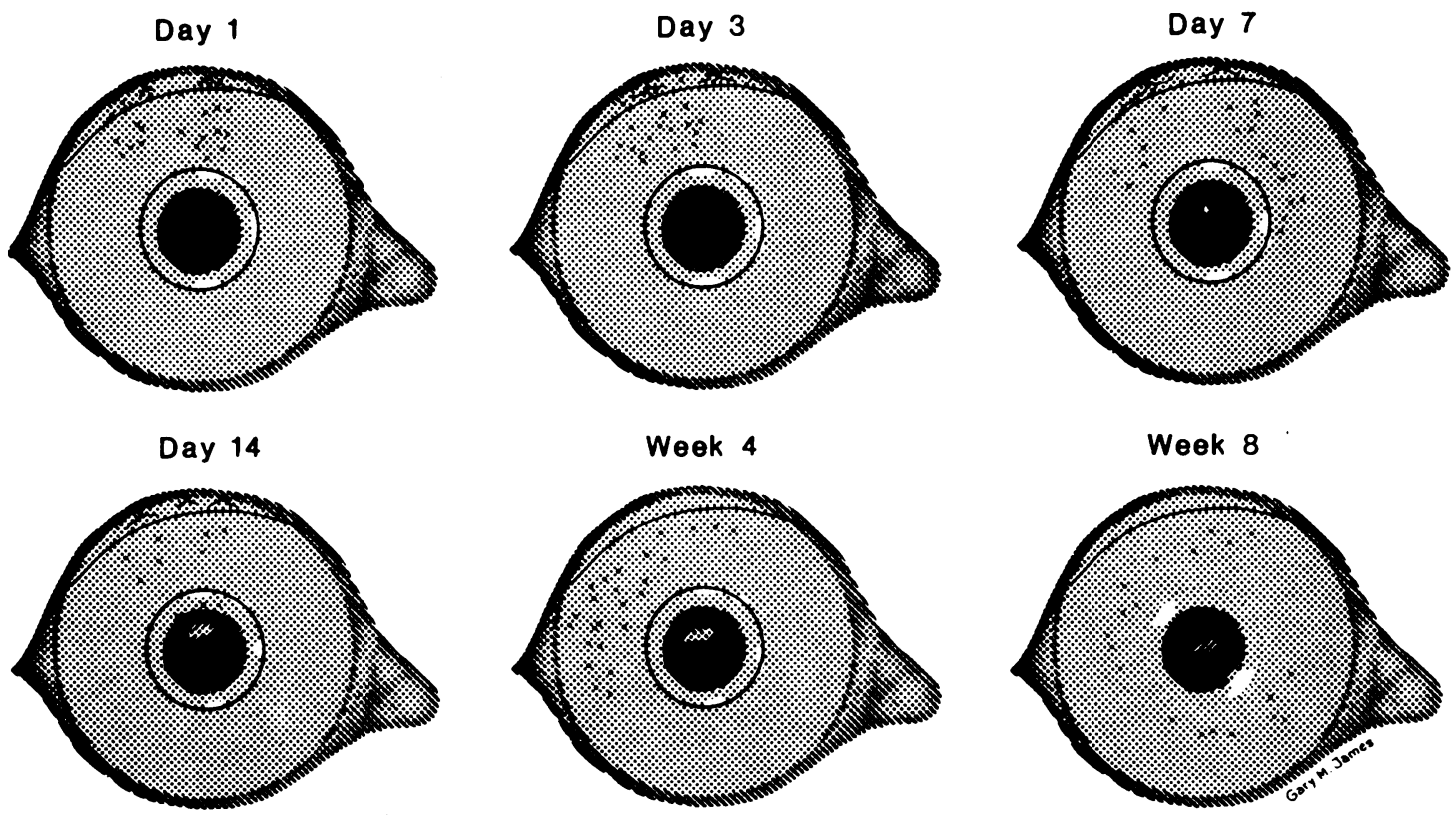

$2 \mathrm{~b}$

Fig. 2 Sequence of events following interlamellar corneal grafting and skin grafting. (a) Untreated: Vessels and cells develop in the region of the incision and small interspace opacities (white) develop at the graft edge. The vessels and cells increase coincidentally with oedema of the proximal recipient stroma involving the graft tissue. Resolution occurs with the appearance of macrophages in the recipient stroma and graft. Opacities (hatched) are noted deep in the graft, and the recipient stroma is slightlv opacified (white). (b) Treated: Vessels and cells develop in the region of the incision and cells reach the donor tissue. The vessels and cells regress. Interspace opacities (white) appear centrally. Macrophages appear in the recipient stroma and graft and the graft edges hecome indistinct. 
Table 1 Rejection response in treated and untreated rabblts at 7 davs and 14 davs

\begin{tabular}{|c|c|c|c|c|}
\hline & & $\begin{array}{l}\text { Marked } \\
\text { rejection }\end{array}$ & $\begin{array}{l}\text { Equivocal } \\
\text { rejection }\end{array}$ & $\begin{array}{l}\text { No } \\
\text { rejection }\end{array}$ \\
\hline $\begin{array}{l}\text { Dav } 7 \\
6 \text { pairs examined }\end{array}$ & $\begin{array}{l}\text { Treated } \\
\text { Untreated }\end{array}$ & $\begin{array}{l}\mathbf{0} \\
2\end{array}$ & $\begin{array}{l}4 \\
4\end{array}$ & $\frac{2}{0}$ \\
\hline $\begin{array}{l}\text { Dav } 14 \\
13 \text { pairs examined }\end{array}$ & $\begin{array}{l}\text { Treated } \\
\text { Untreated }\end{array}$ & $\begin{array}{l}1 \\
9\end{array}$ & $\begin{array}{l}1 \\
1\end{array}$ & $\begin{array}{r}11 \\
2\end{array}$ \\
\hline
\end{tabular}

Table 2 Grading of opacification in recipient stroma

\begin{tabular}{|c|c|}
\hline Appearance & Grade \\
\hline Absolutelv clear & 0 \\
\hline $\begin{array}{l}\text { Diffuse opacification on slit-lamp examination } \pm \text { small } \\
\text { occasional opacities }\end{array}$ & $\mathbf{l}$ \\
\hline $\begin{array}{l}\text { Diffuse opacification just visible to naked eve } \pm \text { occasional } \\
\text { dense opacities }\end{array}$ & ? \\
\hline $\begin{array}{l}\text { Diffuse opacification easily seen by naked eve } \pm \text { small } \\
\text { dense occasional opacities }\end{array}$ & 3 \\
\hline Diffuse dense opacification & 4 \\
\hline
\end{tabular}

Table 3 Score ranges whereby rabbits were allocated into high and low rejection groups

\begin{tabular}{lll}
\hline $\begin{array}{l}\text { Rejection } \\
\text { criteria }\end{array}$ & $\begin{array}{l}\text { Value decided as } \\
\text { low rejection }\end{array}$ & $\begin{array}{l}\text { Value decided as } \\
\text { high rejection }\end{array}$ \\
\hline Stromal opacification & $0-2$ & $3-4$ \\
Stromal vascularisation & $0-1$ & $2-3$ \\
Graft opacities & $0-1$ & $2-3$ \\
Limbal injection & $0-1$ & $2-3$ \\
Total scores & $0-4$ & $5-14$ \\
\hline
\end{tabular}

was graded as shown in Table 2 . Stromal vascularisation, opacification of the graft button, and limbal injection was graded according to a simple 0-3 scale which corresponded to absent, mild, moderate, and intense responses.

At 2 weeks each rabbit was examined and a score decided for each criterion. The total score for each rabbit was also obtained. Rabbits were divided according to their score into either a group displaving absent/mild rejection or a group displaving moderate/marked rejection for each criterion and total score (Table 3 ). The code was then broken, and Table 4 shows the distribution of treated and untreated rabbits within these 2 rejection groups.

Statistical analysis demonstrated a significant difference in the distribution of treated and untreated rabbits within the 2 rejection groups for stromal opacification, stromal vascularisation, and total score of rejection criteria $(p<0 \cdot 05,<0 \cdot 05,<0 \cdot 01$ respectively by chi-square test; Table 5).
Table 4 Distribution of treated and untreated rabbits within low and high rejection groups for each rejection criteria and total score

\begin{tabular}{|c|c|c|c|c|}
\hline \multirow[t]{2}{*}{ Rejection criteria } & \multicolumn{2}{|c|}{$\begin{array}{l}\text { No. in low } \\
\text { rejection group }\end{array}$} & \multicolumn{2}{|c|}{$\begin{array}{l}\text { No. in high } \\
\text { rejection group }\end{array}$} \\
\hline & Treated & Untreated & Treated & Untreated \\
\hline Stromal opacification & 11 & 4 & 2 & 8 \\
\hline Stromal vascularisation & 11 & 3 & 2 & 9 \\
\hline Graft opacities & 12 & 6 & 1 & 6 \\
\hline Limbal injection & 10 & 4 & 2 & 7 \\
\hline Total scores & 11 & 3 & 2 & 9 \\
\hline
\end{tabular}

Table 5 Probability that cyclosporin-A influenced rejection favourably

\begin{tabular}{lll}
\hline Rejection criteria & $\chi^{2}$ & $p<$ \\
\hline Stromal opacification & $4 \cdot 87$ & $\mathbf{0} \cdot(05$ \\
Stromal vascularisation & $6 \cdot 74$ & $\mathbf{0} \cdot() 1$ \\
Graft opacities & $3 \cdot 64$ & NS \\
Limbal injection & $.3 \cdot 53$ & NS \\
Total score & $6 \cdot 74$ & $0 \cdot() 1$ \\
\hline
\end{tabular}

NS= not significant.

averaee scone of mesection chaneEs in theated ano untmeated rasaits

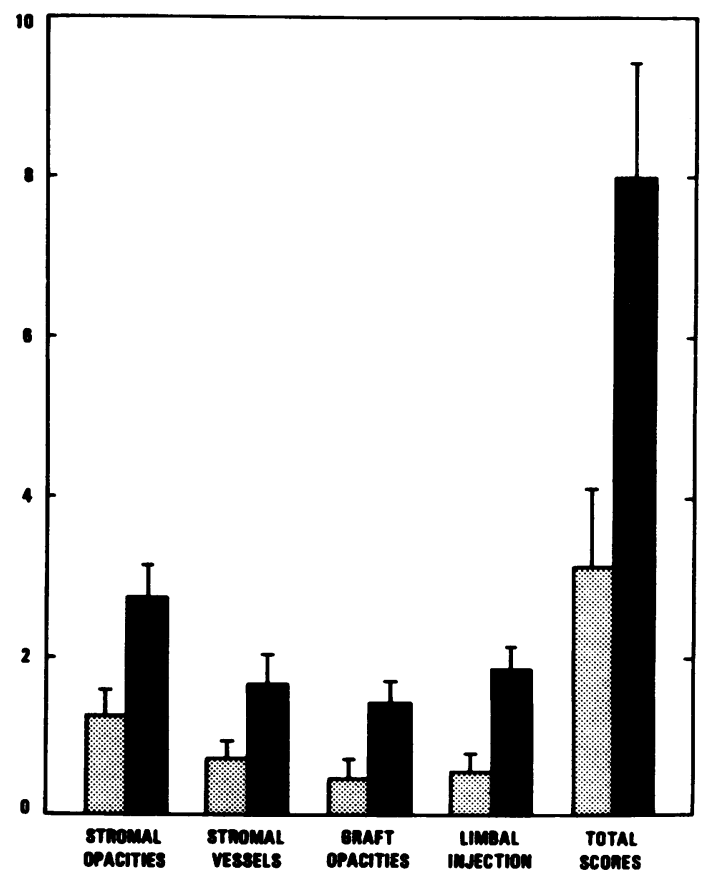

Fig. 3 Average score of rejection criteria and total score in treated and untreated rabbits. Standard errors are shown. Dark shade: untreated rabbits. Light shade: $C v A$ treated rabbits. 


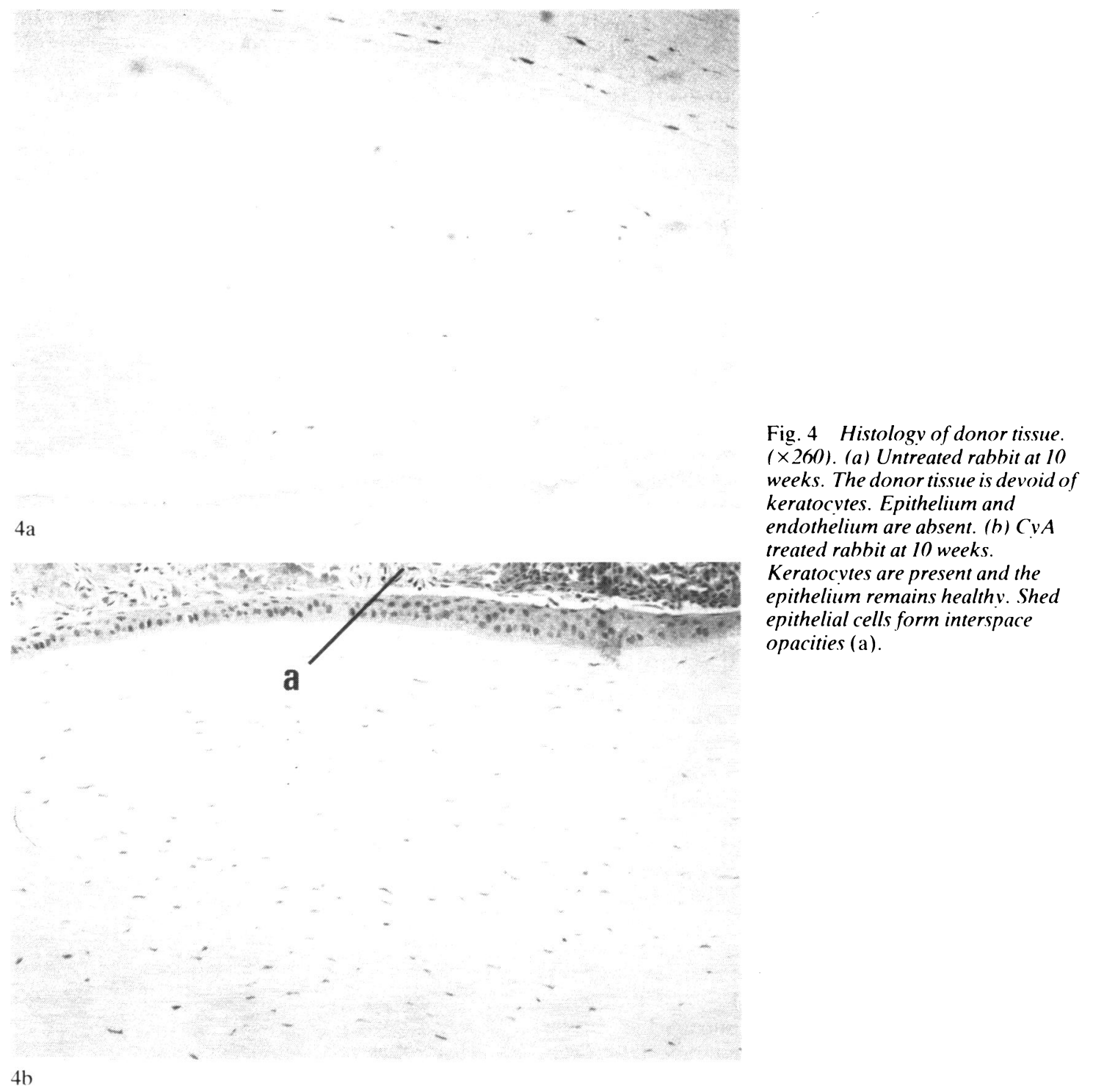

The average score for the rejection criteria in the treated and untreated rabbits are shown with standard errors (Fig. 3).

HISTOI.OGY

Histological examination at 14 davs in the untreated rabbits revealed an inflammatory reaction comprising polymorphonuclear leucocytes, lymphocytes, fibroblasts, and vascularisation in the proximal recipient stroma located in the plane of the original dissection. this reaction extending towards the graft button. The cellular infiltrate was present in the tissue both anterior and posterior to the graft button, and cells invaded the epithelium and endothelium of the donor tissue. Cells were also noted in the graft stroma in reduced numbers. A dense lymphocytic reaction was present in the ciliary body. Histological examination in the treated rabbits revealed no inflammatory reaction other than healing of the incision. Remnants of endothelium were present, and the epithelium was preserved.

Histological examination at 10 weeks in the untreated rabbits (Fig. 4a) revealed an absence of donor epithelium and a marked hypocellularity of the graft 
stroma with extensive areas of necrosis in the deeper lavers. Vessels extended into the graft, macrophages were evident in recipient and donor tissue. and lymphocytes were noted in the ciliary body. In the treated rabbits (Fig. 4b) the graft was intact, with a normal population of keratocytes and an intact epithelium. Macrophages were evident in the donor button and in the recipient stroma. A macrophage and mild lymphocytic reaction was present in the ciliary body.

\section{Discussion}

The results show that $\mathrm{CvA}$ significantly reduced the development of stromal opacification and stromal vascularisation, which were the most obvious signs of graft rejection in this model.

Interspace opacities appeared to correspond with areas of degenerating epithelium. In untreated rabbits they were associated with inflammatory cells. while in treated rabbits they resulted from shed epithelial cells. Whereas oedema of the graft button at 2-4 weeks was a reliable indicator of rejection, the interspace opacity was not.

In this model corneal grafting is attended by the early presence of cells derived from the limbal vessels which develop in response to the incision. In the absence of CvA this cellular infiltrate is followed after an interval of several davs by a marked inflammatory reaction, with intense vascularisation, increased cellular infiltration, and oedema. This protracted reaction resulted in the destruction of epithelium. endothelium, and keratocytes and would almost certainly result in failure of penetrating keratoplasty. The recipient stroma remains vascularised and opacified.

In the presence of $\mathrm{CyA}$ early inflammatory cells appear in the proximal stroma, but there is no subsequent inflammatory response. The observations support the suggestion that $\mathrm{CvA}$ impairs the early stage of antigenic sensitisation of immunocompetent cells.

The prolonged survival of the graft following withdrawal of treatment may be due to an induction of specific tolerance to the antigen by $\mathrm{CyA}$ as described by Green et al.' Alternatively it is possible that the corneal graft regains immune privilege after healing of the incision. It is interesting that Shepherd et al. were unable to induce rejection of a corneal graft in a control rabbit by sensitising 14 days later with a skin graft if the wound was not vascularised ${ }^{8}$ suggesting that the early inflammatory response induced in the locality of the incision constitutes a breakdown of corneal immune privilege.

Cyclosporin A has been shown to prolong survival of penetrating corneal grafts in rabbits, ${ }^{8}$ and the present blind, placebo-controlled study supports this result. The suggested mechanism of action appears to be relevant to corneal grafting and provides a rationale for short-term use of the drug until corneal immune privilege is re-established.

CyA has been used as the immunosuppressive agent in renal transplants in man. ${ }^{5}$ Toxic side effects including transient jaundice and changes in the liver and kidney are reported, ${ }^{2}$ and there may be a $10 \%$ incidence of lymphoma in patients receiving the drug on a long-term basis. ${ }^{2}$ There may be little indication for prolonged use in corneal grafting; consequently it would seem unlikely that side effects will prove to be a hazard. More information on the total dosage of CyA and the incidence of systemic complications is required before short-term use of this drug can be recommended.

We gratefully acknowledge assistance from Dr J. F. Borel of Sandoz. Ltd. Professor Grunsell. Department of Veterinary Medicine. Bristol University. and Miss Clare Carter. Miss Anne McSmvthurs. and Mrs Janet Williams. Pharmacy Department. Bristol Eve Hospital for assistance with preparation and coding of the materials.

\section{References}

1 Borel JF. Feurer C. Magnee C. Stähelen H. Effects of the new anti-lymphocytic peptide cyclosporin $\mathrm{A}$ in animals. Immunologv 1977: 32: 1017-25.

2 Editorial. Lancet 1979: ii: $779-80$.

3 Green CJ. Allison AC. Extensive prolongation of rabbit kidney allograft survival after short term cvclosporin $A$ treatment. Lancet 1978: i: $1182-3$.

4 Calne RY. White DJG. Rolles K. Smith DF. Herbertson BM. Prolonged survival of pig orthoptic heart grafts treated with cyclosporin A. Lancet 1978: i: 1183-5.

5 Calne RY. White DJG. Thiru S. et al. Cvclosporin A in patients receiving renal allografts from cadaver donors. Lancet 1978; ii: 1323-6.

6 Basu PK. Ormsby HL. Studies of immunity with interlamellar corneal homografts in rabbits. Am J Ophthalmol 1957; 44: 598-6)2

7 Green CJ. Allison AC. Precious S. Induction of specific tolerance in rabbits by kidney allografting and short periods of cyclosporin $A$ treatment. Lancet 1979; ii: 12.3-5.

8 Shepherd WFI. Coster DJ. Chin Fook. Rice NSC. Jones BR. Effect of cyclosporin $A$ on the survival of corneal grafts in rabbits. Br J Ophthalmol 1980; 64: 148-53. 